\title{
Fibroblast Growth Factor 2 Augments Transforming Growth Factor Beta 1 in Inducing Epithelial- Mesenchymal Transition in Human Lung Epithelial Cells
}

\section{Lamis M.F. El-Baz}

Suez Canal University Faculty of Science

Nahla M. Shoukry

Suez Canal University Faculty of Science

Mohamed L. Salem

Tanta University

Hani S. Hafez

Suez Canal University Faculty of Science

Robert D. Guzy ( $\square$ rguzy1@bsd.uchicago.edu )

University of Chicago https://orcid.org/0000-0001-8420-6177

\section{Research article}

Keywords: Fibroblast Growth Factor, Transforming growth factor, Epithelial-mesenchymal transition, Lung injury, Epithelial cells.

Posted Date: January 14th, 2020

DOI: https://doi.org/10.21203/rs.2.10955/v2

License: (c) (i) This work is licensed under a Creative Commons Attribution 4.0 International License.

Read Full License 
The authors have withdrawn the journal submission associated with this preprint and requested that the preprint also be withdrawn. 